\title{
A Rapid Procedure for the Detection of Archaebacterial Lipids in Halophilic Bacteria
}

\author{
By H. N. M. ROSS, M. D. COLLINS, B. J. TINDALL AND \\ W. D. GRANT* \\ Department of Microbiology, School of Medicine and School of Biological Sciences, \\ University of Leicester, Leicester LE1 7RH
}

(Received 19 September 1980)

\begin{abstract}
Whole-organism acid methanolysates of strains of halophilic bacteria were examined for glycerol diether moieties and other long-chain constituents by thin-layer chromatography. Glycerol diether moieties were detected only in acid methanolysates of archaebacterial halophiles. Eubacterial halophiles contained only fatty acid methyl esters. Spots on thin-layer plates attributed to diether moieties were further identified by infrared spectroscopy. Thin-layer chromatographic analysis of whole-organism methanolysates provides a simple and rapid method of distinguishing archaebacterial halophiles from eubacterial halophiles. The majority of archaebacterial halophiles produced only one chromatographically distinct glycerol diether moiety, but certain strains, including the recently described alkalophilic halophiles, produced two distinct moieties.
\end{abstract}

\section{INTRODUCTION}

Molecular genealogical analysis based upon transfer and ribosomal RNA sequence homologies has revealed that the bacteria do not constitute a phylogenetically monolithic grouping (see Woese \& Fox, 1977). The kingdom Procaryotae actually comprises two phylogenetically distinct groups - the 'archaebacteria', and the 'eubacteria' including the cyanobacteria. The first organisms recognized to be archaebacteria were the methanogens (Woese \& Fox, 1977) and subsequent studies indicated that certain thermoacidophiles (Caldariella, Sulfolobus and Thermoplasma) and extreme halophiles (Halobacterium and Halococcus) should also be included in this group (Woese et al., 1978). Amongst other distinctive features of the archaebacteria are the absence of cell wall peptidoglycan (Brown \& Cho, 1970; Kandler \& Hippe, 1977) and the presence of ether-linked lipids (deRosa et al., 1974, 1980; Kates, 1978; Tornabene \& Langworthy, 1978; Balch et al., 1979).

At present, archaebacteria have only been isolated from a few restricted environments and there is considerable interest in establishing whether they occur elsewhere. The assignment of a particular isolate to the archaebacteria is currently a laborious procedure. During recent investigations into the taxonomic status of alkalophilic halophiles from Kenyan soda lakes (Tindall et al., 1980; W. D. Grant, unpublished results) we have developed a rapid screening procedure for detecting archaebacteria, based on the presence of the ether-linked lipids. The ether lipids of halophilic bacteria have been the subject of extensive investigation by Kates and associates (Sehgal et al., 1962; Kates et al., 1966; Joo et al., 1968; Kates, 1978), but no simple procedure existed for the detection of these lipids. This paper demonstrates that the pattern of spots corresponding to glycerol diether moieties obtained by thin-layer chromatographic (t.l.c.) analysis of whole-organism methanolysates (Minnikin et al., 1975) provides a means of distinguishing archaebacterial halophilic taxa from eubacterial halophilic 
taxa. The method described is rapid, simple, requires no expensive equipment and should be applicable in routine laboratories.

\section{METHODS}

Cultures and cultivation. Details of the test strains and their sources are shown in Table 1. Actinopolyspora halophila and members of the genera Halobacterium and Halococcus were grown at $37^{\circ} \mathrm{C}$ in liquid shake culture on the medium of Payne et al. (1960) with the exception of Halobacterium volcanii which was grown in the

Table 1. Grouping of test strains based on chromatographic analysis of whole-organism methanolysates

(a) Halophilic bacteria lacking fatty acid methyl esters but containing glycerol diether moieties

Strain Source*

Halobacterium cutirubrum
Halobacterium halobium
Halobacterium halobium
Halobacterium halobium
Halobacterium halobium
Halobacterium saccharovorum
Halobacterium salinarium
Halobacterium salinarium subsp. proteolyticum
Halobacterium salinarium
Halobacterium simoncinii subsp. neapolitanum
Halobacterium sp. (Cagliari)
Halobacterium trapanicum
Halobacterium volcanii
Halococcus morrhuae
Halococcus morrhuae
Halococcus morrhuae
Sarcina morrhuae $\dagger$
Sarcina litoralis $\dagger$
Sarcina sreenivasani $\dagger$
Alkalophilic halophiles: SP1
$\quad$ SP2
MS3

NCMB 763

NCMB 736

CCM 2090

NCMB 777

NCMB 2080

NCMB 2081

NCMB 764

NCMB 786

CCM 2148

NCMB 773

NCMB 768

NCMB 784

NCMB 2012

NCMB 787

NCMB 749

CCM 2526

NCMB 761

NCMB 757

NCMB 776

W. D. Grant

W. D. Grant

W. D. Grant

(b) Halophilic bacteria containing fatty acid methyl esters but lacking glycerol diether moieties

Strain Source*

Actinopolyspora halophila
Brevibacterium halotolerans
Ectothiorhodospira halophila
Ectothiorhodospira sp. (S1)
Flavobacterium halmephilum
Micrococcus halobius
Micromonospora halophytica subsp. halophytica
Micromonospora halophytica subsp. nigra
Paracoccus halodenitrificans
Planococcus halophilus
Pseudomonas beijerinckii
Vibrio costicola

ATCC 27976
ATCC 25096
DSM 244
W. D. Grant
NCMB 1971
CCM 2526
NRRL 2998
NRRL 3097
NCMB 700
ATCC 27964
NCIB 9041
NCMB 701

* ATCC, American Type Culture Collection, Rockville, U.S.A.; CCM, Czechoslovak Collection of Microorganisms, Brno, Czechoslovakia; DSM, Deutsche Sammlung von Mikroorganismen, Munich, W. Germany; NCIB, National Collection of Industrial Bacteria, Aberdeen, Scotland; NCMB, National Collection of Marine Bacteria, Aberdeen, Scotland; NRRL, Northern Utilization Research and Development Division, U.S. Department of Agriculture, Illinois, U.S.A.; W. D. Grant, Department of Microbiology, University of Leicester, Leicester.

† Now classified as Halococcus morrhuae by Kocur \& Hodgkiss (1973). 
medium of Mullakhanbhai \& Larsen (1975). Flavobacterium halmephilum, Micrococcus halobius, Micromonospora halophytica, Paracoccus halodenitrificans, Pseudomonas beijerinckii and Vibrio costicola were grown in liquid shake culture in nutrient broth no. 2 (Oxoid) supplemented with $10 \%(\mathrm{w} / \mathrm{v}) \mathrm{NaCl}$ at $30^{\circ} \mathrm{C}$. Brevibacterium halotolerans was grown in nutrient broth no. 2 (Oxoid) supplemented with $5 \%(\mathrm{w} / \mathrm{v}) \mathrm{NaCl}$ at $30^{\circ} \mathrm{C}$. The alkalophilic halophiles (SP1, SP2, MS3) and Ectothiorhodospira strains (E. halophila, S1) were grown in the media of Tindall et al. (1980) and Imhoff \& Trüper (1977), respectively, at $37{ }^{\circ} \mathrm{C}$. Planococcus halophilus was grown at $30^{\circ} \mathrm{C}$ in liquid medium containing tryptone $\left(5 \mathrm{~g} \mathrm{l}^{-1}\right)$, proteose peptone $\left(5 \mathrm{~g} \mathrm{l}^{-1}\right)$ and $\mathrm{NaCl}$ $\left(58.4 \mathrm{~g} \mathrm{l}^{-1}\right)$. Cultures were checked for purity at maximum growth, harvested by centrifugation $(10000 \mathrm{~g})$ and freeze-dried.

Whole-organism acid methanolysis. Dry cells $(100 \mathrm{mg})$ were mixed with methanol $(3 \mathrm{ml})$, toluene $(3 \mathrm{ml})$ and conc. $\mathrm{H}_{2} \mathrm{SO}_{4}(0.1 \mathrm{ml})$ and heated at $50^{\circ} \mathrm{C}$ for 15 to $18 \mathrm{~h}$ as described by Minnikin et al. (1975). The long-chain components were extracted from this mixture by adding $1.5 \mathrm{ml}$ hexane (Minnikin et al., 1975). Hexane extracts were chromatographed on Merck silica gel $60 \mathrm{~F}_{254}$ aluminium-backed thin-layer plates $(10 \times 10 \mathrm{~cm})$ using petroleum ether (b.p. 60 to $80^{\circ} \mathrm{C}$ )/diethyl ether $(85: 15, \mathrm{v} / \mathrm{v})$ as developing solvent (Minnikin et al., 1975). Further resolution of glycerol diether moieties was achieved by developing the t.l.c. plate in one dimension using petroleum ether (b.p. 60 to $80^{\circ} \mathrm{C}$ )/acetone $(95: 5, \mathrm{v} / \mathrm{v})$ followed by redevelopment in the same direction using toluene/acetone $(97: 3, \mathrm{v} / \mathrm{v})$. Confirmation of the results obtained from the whole-organism methanolysis method of Minnikin et al. (1975) was achieved by using the anhydrous methanolic $\mathrm{HCl}$ procedure of Kates et al. (1966) on the total lipid fraction of the test strains. Lipids were revealed by spraying the t.l.c. plates with $10 \%$ dodecamolybdophosphoric acid in absolute ethanol and heating for $15 \mathrm{~min}$ at $150^{\circ} \mathrm{C}$. All lipids appeared as dark blue spots on a yellow background.

\section{RESULTS AND DISCUSSION}

The patterns obtained by chromatographic analysis [using petroleum ether (b.p. 60 to $80^{\circ} \mathrm{C}$ )/diethyl ether; $85: 15, \mathrm{v} / \mathrm{v}$ l of methanolysates of halophilic bacteria are shown in Fig. 1 .

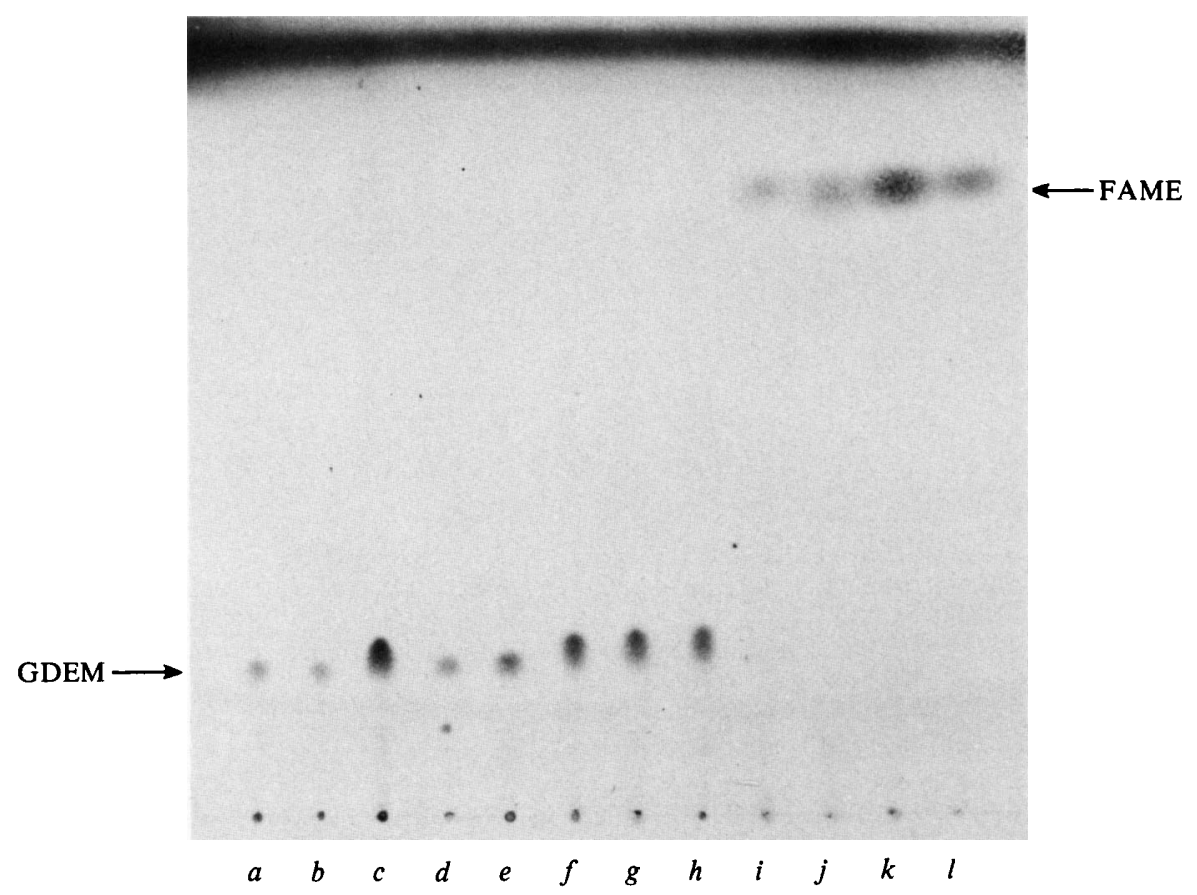

Fig. 1. Thin-layer chromatographic analysis of whole-organism methanolysates of $(a)$ Halococcus morrhuae NCMB 787, (b) Halococcus morrhuae NCMB 749, (c) Halobacterium halobium NCMB $777,(d)$ Halobacterium salinarium NCMB 764, (e) Halobacterium volcanii NCMB 2012, ( $f)$ SP $1,(g)$ SP2, (h) MS3, (i) Planococcus halophilus ATCC 27964, (j) Actinopolyspora halophila ATCC 27976, (k) Vibrio costicola NCMB 701 and (l) Pseudomonas beijerinckii NCIB 9041. Plates were developed in petroleum ether (b.p. 60 to $\left.80^{\circ} \mathrm{C}\right)$ /diethyl ether $(85: 15, \mathrm{v} / \mathrm{v})$. FAME, fatty acid methyl esters; GDEM, glycerol diether moieties. 


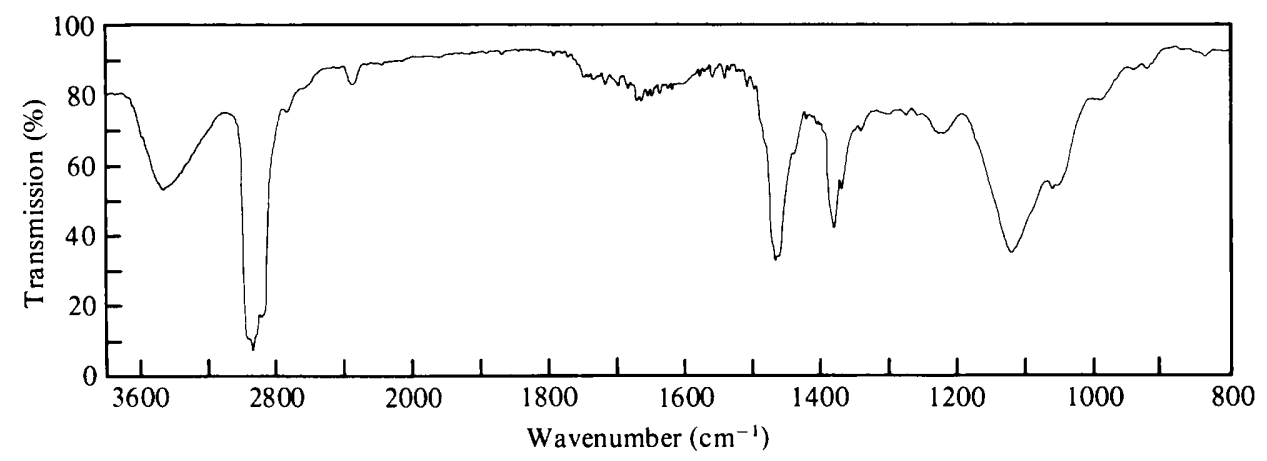

Fig. 2. Infrared spectrum of the purified glycerol diether moiety from Halobacterium cutirubrum NCMB 763.

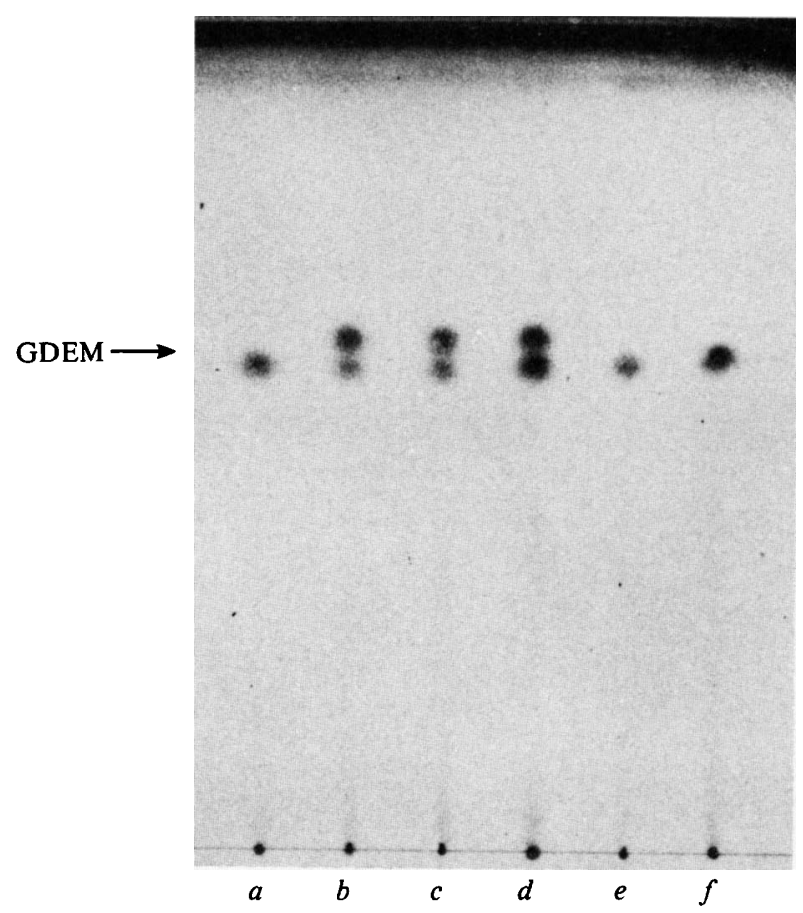

Fig. 3. Thin-layer chromatographic analysis of whole-organism methanolysates of (a) Halobacterium cutirubrum NCMB 763, (b) SP1, (c) SP2, (d) MS3, (e) Halobacterium salinarium NCMB 764 and $(f)$ Halococcus morrhuae NCMB 749. Plates were first developed in petroleum ether (b.p. 60 to $\left.80^{\circ} \mathrm{C}\right)$ /acetone $(95: 5, \mathrm{v} / \mathrm{v})$, then dried and redeveloped in the same direction in toluene/acetone $(97: 3$, $\mathrm{v} / \mathrm{v})$. GDEM, glycerol diether moieties.

Spots with $R_{F}$ values of about 0.2 were attributable to glycerol diether moeities (GDEM) whereas components having $R_{F}$ values greater than 0.6 corresponded to methyl esters of non-hydroxylated fatty acids (FAME) (Minnikin et al., 1975, 1978). On the basis of their chromatographic patterns, the test strains were divided into two broad groups: taxa containing GDEM and lacking FAME (Table $1 a$ ), and taxa containing FAME only (Table $1 b$ ). The absence of ester-containing lipids in the archaebacterial halophiles (Table $1 a$ ) was demonstrated by a negative reaction with the hydroxamate $/ \mathrm{FeCl}_{3}$ ester spray reagent (Skidmore \& Entenman, 1962; Kates, 1975). This reagent unequivocally distinguishes 
glyceroi diether moieties from ester-containing components such as hydroxylated fatty acid methyl esters, which have similar $R_{F}$ values (about 0.2 ). The presumptive diether moieties, purified by preparative t.l.c., were further confirmed by infrared spectroscopy. Notable was the complete absence of ester absorption in the range 1730 to $1750 \mathrm{~cm}^{-1}$ (Fig. 2). However, the spectra did show strong absorption bands indicative of long-chain groups $(2960,2940$, 2880 , and $\left.1460 \mathrm{~cm}^{-1}\right)$, OH groups $\left(3400 \mathrm{~cm}^{-1}\right.$, broad) and ether $\mathrm{C}-\mathrm{O}-\mathrm{C}$ groups $\left(1120 \mathrm{~cm}^{-1}\right.$ ) (Fig. 2). Doublets at 1365 to $1380 \mathrm{~cm}^{-1}$ were indicative of isopropyl units.

It was noted that the glycerol diether spots of certain archaebacterial strains (spots $c, f, g$ and $h$, Fig. 1) were elongated. An attempt to resolve these components further was made by developing the t.l.c. plate in one dimension using petroleum ether (b.p. 60 to $80^{\circ} \mathrm{C}$ )/acetone $(95: 5, \mathrm{v} / \mathrm{v})$ followed by redevelopment in the same direction in toluene/acetone $(97: 3, \mathrm{v} / \mathrm{v})$. Using this procedure, two separate spots were observed, suggesting two distinct glycerol diether moieties (Fig. 3). Further confirmation that these strains contain two chromatographically distinct glycerol diether moieties was obtained by applying the alternative acid methanolysis procedure of Kates et al. (1966). Chromatographic analysis of these extracts yielded identical results. This is the first report of two distinct glycerol diether moieties within the extreme halophiles. The extensive investigations of Kates and associates were confined to strains (notably Halobacterium cutirubrum) which possess only one major glycerol diether moiety (Fig. 3). Work is in progress to elucidate the structural relationship between these two chromatographically distinct diether moieties.

We believe that thin-layer chromatographic analysis of whole-organism methanolysates provides a simple and effective way of distinguishing archaebacterial halophiles from eubacterial halophiles. In addition, the methanolysis procedure of Minnikin et al. (1975) can be scaled down to about 15 to 20 bacterial colonies and thus provides a useful screening procedure for archaebacterial halophiles.

H. N. M. Ross and B. J. Tindall are grateful to the Science Research Council for studentship grants. W. D. Grant is grateful to the Royal Society for support.

\section{REFERENCES}

Balch, W. E., Fox, G. E., Magrum, L. J., Woese, C. R. \& Wolfe, R. S. (1979). Methanogens: reevaluation of a unique biological group. Microbiological Reviews 43, 260-292.

Brown, A. D. \& Cho, K. Y. (1970). The walls of the extremely halophilic cocci: Gram-positive bacteria lacking muramic acid. Journal of General Microbiology 62, 267-270.

IMHOFF, J. F. \& TRÜPER, H. G. (1977). Ectothiorhodospira halochloris sp. nov, a new extremely halophilic phototrophic bacterium containing bacteriochlorophyll b. Archives of Microbiology 114, 115-121.

Joo, C. N., Shier, T. \& Kates, M. (1968). Characterization and synthesis of mono- and diphytanyl ethers of glycerol. Journal of Lipid Research 9, 782-788.

KANDLER, O. \& HiPPE, H. (1977). Lack of peptidoglycan in the cell walls of Methanosarcina barkeri. Archives of Microbiology 113, 57-60.

KATES, M. (1975). Techniques of Lipidology. Amsterdam: North-Holland Publishing Co.

KATES, M. (1978). The phytanyl ether-linked polar lipids and isoprenoid neutral lipids of extremely halophilic bacteria. Progress in Chemistry of Fats and other Lipids 15, 301-342.

Kates, M., Joo, C. N., Kushner, D. J. \& Gibbons,
N. E. (1966). Aliphatic diether analogs of glyceridederived lipids. IV. The occurrence of di-O-dihydrophytyl glycerol ether containing lipids in extremely halophilic bacteria. Biochemistry 5, 40924099.

KocuR, M. \& Hodgkiss, W. (1973). Taxonomic status of the genus Halococcus Schoop. International Journal of Systematic Bacteriology 23, $151-156$.

Minnikin, D. E., Alshamaony, L. \& Goodfellow, M. (1975). Differentiation of Mycobacterium, Nocardia and related taxa by thin-layer chromatographic analysis of whole-organism methanolysates. Journal of General Microbiology 88, 200-204.

Minnikin, D. E., Goodfellow, M. \& Collins, M. D. (1978). Lipid composition in the classification and identification of coryneform and related taxa. In Coryneform Bacteria, pp. 85-160. Edited by I. J. Bousfield \& A. G. Callely. London: Academic Press. Mullakhanbhai, M. F. \& LaRSeN, H. (1975). Halobacterium volcanii spec. nov., a Dead Sea Halobacterium with a moderate salt requirement. Archives of Microbiology 104, 207-214.

Payne, J. I., Sehgal, S. N. \& Gibbons, N. E. (1960). Immersion refractometry of some halophilic bacteria. Canadian Journal of Microbiology 6. $9-15$. 
deRosa, M., Gambacorta, A., Minale, L. \& Bu'LOCK, J. D. (1974). Cyclic diethers from very thermophilic acidophilic bacteria. Chemical Communications, 543-544.

deRosa, M., DeRosa, S., Gambacorta, A. \& Bu'LOCK, J. D. (1980). Structure of Calditol, a new branched-chain nonitol, and of the derived tetraether lipids in thermoacidophilic archaebacteria of the Caldariella group. Phytochemistry 19, 249-254.

Sehgal, S. N., Kates, M. \& Gibbons, N. E. (1962). Lipids of Halobacterium cutirubrum. Canadian Journal of Biochemistry and Physiology 40, 69-81.

Skidmore, W. D. \& Entenman, C. (1962). Twodimensional thin-layer chromatography of rat liver phosphatides. Journal of Lipid Research 3, 471475 .
Tindall, B. J., Mills, A. A. \& Grant, W. D. (1980). An alkalophilic red halophilic bacterium with a low magnesium requirement from a Kenyan soda lake. Journal of General Microbiology 116, 257-260.

ToRnabene, T. G. \& LANGWorthy, T. A. (1978). Diphytanyl and dibiphytanyl glycerol ether lipids of methanogenic archaebacteria. Science 203, 51-53.

Woese, C. R. \& Fox, G. E. (1977). Phylogenetic structure of the prokaryotic domain: the primary kingdoms. Proceedings of the National Academy of Sciences of the United States of America 74, 50885090.

Woese, C. R., Magrum, L. G. \& Fox, G. E. (1978). Archaebacteria. Journal of Molecular Evolution 11, 245-252. 